DOI: $10.17516 / 1997-1370-0853$

УДК 336.02

\title{
Russia in Global Digital Tax Reform: Together or Apart?
}

\author{
Nikolai S. Milogolova,b and Azamat B. Berberov*c, d \\ ${ }^{a}$ Financial Research Institute under the Ministry of Finance \\ Moscow, Russian Federation \\ ${ }^{b}$ Russian Presidential Academy of National Economy and Public Administration \\ Moscow, Russian Federation \\ ${ }^{c}$ Gaidar Institute for Economic Policy \\ Moscow, Russian Federation \\ ${ }^{d}$ Financial University under the Government of the Russian Federation \\ Moscow, Russian Federation
}

Received 15.04.2020, received in revised form 21.08.2020, accepted 14.09.2021

\begin{abstract}
The goal of this research is to develop policy proposals for a reform of Russian corporate income tax legislation. The paper reviews and analyses international and Russian tax policy context and ongoing reforms that aim to address the challenges of the digital economy. It is shown that different states have been implementing unilateral measures in their respective tax legislation due to the absence of global consensus about coordinated reform. This leads to increasing complexity and uncertainty for digital businesses and tax administrations. Considering that the digital tax reform agenda is highly relevant for Russia for fiscal reasons, several ideas for developing Russian tax rules in this context are proposed, including amendments to the concept of corporate residence, introducing a digital services tax as an interim measure, amending the mechanism of withholding tax on royalties and clarifying the tax characterisation of supplies in digital form. This article was prepared as part of research by state assignment at the Russian Academy of National Economy and Public Administration.
\end{abstract}

Keywords: digitalisation, international taxation, tax system, global economy, digital tax, tax residence, OECD, Russia.

Research area: financial policy; tax policy.

Citation: Milogolov, N.S., Berberov, A.B. (2021). Russia in global digital tax reform: together or apart? J. Sib. Fed. Univ. Humanit. soc. sci., 14(11), 1731-1745. DOI: 10.17516/1997-1370-0853

(C) Siberian Federal University. All rights reserved

* Corresponding author E-mail address: berberov@iep.ru 


\title{
Россия в международной цифровой налоговой реформе: общий или индивидуальный путь?
}

\author{
Н.С. Милоголов ${ }^{a, 6}$, А.Б. Берберовв, Г \\ ${ }^{a}$ Научно-исследовательский финансовый институт \\ Министерства финансов Российской Федераџии \\ Российская Федерация, Москва \\ ${ }^{6}$ Российская академия народного хозяйства \\ и государственной службы при Президенте Российской Федераџии \\ Российская Федераџия, Москва \\ ${ }^{8}$ Институт экономической политики им. Е. Т. Гайдара \\ Российская Федерачия, Москва \\ ${ }^{2}$ Финансовый университет при Правительстве РФ \\ Российская Федерация, Москва
}

\begin{abstract}
Аннотация. Целью данного исследования является разработка предложений по реформе российского законодательства в части налога на прибыль организаций в условиях становления цифровой экономики. Для этого в работе рассматриваются международные налоговые инициативы по адаптации налоговых систем к новым вызовам в совокупности с анализом текущего состояния российской налоговой системы в «цифровом» контексте. Установлено, что на сегодняшний день государства следуют политике внедрения односторонних мер в налоговое законодательство в связи с отсутствием глобального консенсуса относительно реализации скоординированной реформы. Следование такому сценарию приводит к росту правовой неопределенности для бизнеса и налоговых органов. Учитывая, что реформа корпоративного налогообложения в «цифровых» условиях имеет стратегическое значение для России, авторы предлагают рекомендации, направленные на совершенствование налогового законодательства, среди которых можно выделить совершенствование концепции резидентства юридических лиц, введение временного налога на оказание цифровых услуг, трансформацию механизма удержания налога у источника на исходящие роялти и уточнение налоговой классификации услуг, оказываемых в цифровой форме.
\end{abstract}

Ключевые слова: цифровизация, международное налогообложение, цифровая экономика, цифровой налог, налоговое резидентство, ОЭСР, Россия.

Научные специальности: 12.00.04 - финансовое право; налоговое право; бюджетное право; 08.00.10 - финансы, денежное обращение и кредит.

\section{Introduction}

International tax law is currently undergoing a process of significant reform at global tax governance level. This work is coordinated mostly by the Organisation of Economic Co-operation and Development (OECD) as part of its Base Erosion and Profits Shifting (BEPS) project. Under BEPS Project both OECD and non-OECD states are cooperating and harmonising their international tax policies to promote international economic coop- eration and counter fiscal evasion. The aim of these reforms is to adapt the corporate income tax systems in individual states so that it can face modern challenges such as digitalisation and tackle harmful tax competition and offshore tax avoidance. These issues are interrelated because digitalisation can ease tax competition and create new opportunities for tax evasion.

Russia is a large and growing market for foreign digitalised businesses, and its own 
economy is currently going through a process of digitalisation. Therefore, tax law reform that seeks to adapt existing methodology for the new digital reality is on the agenda of Russian tax policymakers. ${ }^{1}$ Such putative reform requires international consistency and a solid rethinking of the existing rules at domestic level. The goal of reform should be to create a level playing field for foreign and domestic digital businesses and ensure the neutral treatment of digital and non-digital business models while preventing opportunities for tax avoidance. In this research, we discuss scenarios and building blocks for international and domestic tax policy reform in Russian context.

The paper is structured as follows. Following this introduction, Section 2 provides a review of the theoretical and conceptual background of tax challenges relating to digitalisation based primarily on findings from OECD reports and theoretical literature. In Section 3, we formulate the key problem that we are trying to solve. In Section 4, we outline our research approach. In Section 5, we discuss international tax policy developments at a global level and tential reform. Section 7 concludes and summarises the key results.

\section{Theoretical \\ and conceptual framework}

Widespread penetration of digital technologies into all areas of life has resulted in a hastening of the process of structural economic transformation. The use of digital technologies has led to a significant transformation of existing business models and to the appearance of new ones (OECD, 2018). It also contributes to the internationalisation of all aspects of business (Devereux, 2017) explained by the relatively low cost of entering foreign markets and the potential for quickly increasing the supply of successful digital products.

Considering that the existing system of international taxation was developed for traditional (non-digital) international businesses, it now requires some kind of 'digital transformation'. In the opinion of experts at the OECD's Centre for Tax Policy and Administration, the following barriers for international tax rules require in-depth revision (see Table 1).

Table 1. Challenges of digitalisation and the international tax system

\begin{tabular}{|c|c|l|}
\hline № & Criteria & \multicolumn{1}{c|}{ Description of the challenge } \\
\hline 1 & Nexus & $\begin{array}{l}\text { Defining tax nexus with jurisdiction, considering the falling importance of foreign } \\
\text { companies' physical presence in order to do business in a source/market state. }\end{array}$ \\
\hline 2 & Data & $\begin{array}{l}\text { Tax delineating, accounting and characterising the share of value creation, attributed } \\
\text { to a data (provided both by individuals and businesses) and the processing of this data } \\
\text { with digital technologies. }\end{array}$ \\
\hline 3 & Characterisation & $\begin{array}{l}\text { Characterisation of payments made by new types of digitalised business for tax pur- } \\
\text { poses (e. g. in cloud computing businesses). }\end{array}$ \\
\hline
\end{tabular}

Source: Compiled by the authors based on OECD data (OECD, 2018)

unilateral measures taken by individual states. In Section 6, we formulate key tax challenges in Russia and discuss several barriers for po-

\footnotetext{
1 See, for example: Osnovnye napravlenija bjudzhetnoj, nalogovoj i tamozhenno-tarifnoj politiki na 2020 god i na planovyj period 2021 i 2022 godov [The main directions of budget, tax and customs and tariff policy for 2020 and for the planning period of 2021 and 2022] (2019). Available at: https://minfin.gov.ru/common/upload/library/2019/10/main/ ONBNiTTP 2020-2022.pdf
}

The global COVID-19 pandemic has shown that these challenges tend to expand. As tax revenues from traditional industries fall due to economic downturn, additional taxation of the digital sector can potentially compensate for this loss of fiscal revenue. However, considering current growth in the volume in worldwide digital transactions, no country is yet able to tax efficiently the local share of income that 
foreign digital businesses obtain from its market. This problem can be solved either unilaterally or multilaterally.

\section{Statement of the problem}

All methodological problems concerning the current crisis of international tax rules are highly relevant to Russia for a variety of reasons. First, there are currently no instruments in Russian tax law that result in the efficient taxation of local profits of foreign digitalised companies that have merely a virtual presence in Russia. Second, Russia is a large and growing market for foreign digitalised businesses, and therefore the profits of these in Russia are undertaxed. Third, Russia is home to two large digital platforms (Yandex and Mail.ru) and a net exporter of IT services; therefore, it has an interest in sustainable and long-term global digital tax reform. Fourth, Russia suffers from a problem of tax base erosion and profit shifting, and aggressive tax planning with the low-tax jurisdictions that can increase in the digital reality. Fifth, Russian tax law needs a systematic update to be in line with the development of new digital businesses to make rules certain and clear in this area. Finally, Russia is a G20 economy and a participant in OECD's BEPS project; therefore, it is an important player in the global tax governance arena.

All of these issues could potentially lead to a high level of uncertainty, losses of revenue, subsequent losses in the global tax competition game and distortion of the competitive level playing field in the local market in favour of foreign digitalised companies. The problem that the authors are trying to solve with this research is how to develop Russian tax law and policy approaches to properly address the tax challenges of digitalisation.

\section{Methods}

In this research we highlight and compare the OECD's tax policy view and individual countries' experiences in implementing unilateral digital tax reforms. This analysis allows us to show an important tax policy context and formulate recommendations to further develop international tax rules in Russia's domestic legislation and its approach to international tax treaty policy.

\section{International tax policy discussion outline: A global consensus or the development of unilateral measures?}

A multilateral solution requires a coordinated approach in reforming international tax rules. The OECD, as a key player in global tax governance, is currently developing such a consensual approach under the continuation of its BEPS project (OECD, 2015). Reports by the OECD related to digital business taxation show that developing, emerging and developed countries participating in the BEPS project agree on the importance of achieving a co-ordinated solution for the reform of the international tax system. However, they hold differing positions on areas under discussion such as the design, depth and scope of such reform (OECD, 2018). Besides working on a proposal for radical global tax reform (Pillar 1 Proposal), the OECD is also developing several technical documents whereby narrow aspects of international tax rules are discussed, including the characterisation of digital transactions and concept of corporate tax residence.

One such example is the characterisation of digital payments as royalties or business income in the Commentaries to OECD Model Tax Convention (2017). The key idea developed in this document is the use of the de minimis principle as a borderline criterion. The essence of this principle is the analysis of the economic and legal substance of transactions to make conclusions about the volume of copyright for the transfer of digital products to the customer. If such volume of copyright exceeds the de minimis threshold, a transaction could be classified as the provision of rights for the use of intellectual property, and therefore income could be classified as royalties. Otherwise, according to paragraph 2 of the Commentary, income should be classified as business income (OECD, 2017, p. 275).

Another example is the concept of corporate residence in digitalised economic reality. Although the OECD has discussed this concept for a long period of time, the solution it found 
can be considered problematic. The OECD notes that situations of double tax residence of corporate entities are exceedingly rare in practice and therefore could be resolved by mutual agreement procedure and consultation between the competent authorities of both states (OECD, 2021). We suggest that, considering the growth of digitalised businesses and the use of digital technologies, such a position is not sustainable in the long term. Increasingly, international digital businesses are managed in practice by executive teams who communicate across digital networks and reside in different states, putting pressure on the concept of corporate residence (Lucas-Mas, 2021). This can be especially hard if the executives are digital nomads without vital interests in any state (Kostic, 2019).

So, considering the de facto inability of the OECD as a global tax coordination body until recently to reform urgently and consistently the international tax system due to an endless list of practical, technical and methodological issues, we can observe a global tendency towards unilateral measures. Examples of such measures are listed in Table 2.

Unilateral tax reform measures are attractive, especially for large developing and emerg- ing economies with a high number of users of digital products. Such reform is politically acceptable, as a tax on foreigners and can generate revenues for funding government projects. Nevertheless, the introduction of such unilateral measures can contradict the basic principles of existing international tax rules and therefore create economic barriers and distortions, including double or even multiple taxation of same economic profits across several jurisdictions (European Parliament, 2019). The widespread adoption of unilateral measures can potentially lead to international disputes and disagreements if treaty partners have an opposing economic interest. One recent example was a warning by the United States embassy in Prague of potential economic sanctions if the Czech Republic planned to introduce a unilateral digital services tax at a rate of $7 \%$ (U.S. warns, 2020).

Unilateral reforms can potentially lead to legal uncertainty for foreign companies and complexities with the administration of new taxes. This can also be the case when such taxes impose a wider scope of taxation at the source state than existing tax treaties. Israel declared its intention to introduce unilaterally a digital services tax in the middle of 2019

Table 2. Unilateral measures aimed at taxation of digital business profits.

\begin{tabular}{|c|c|}
\hline Measure & Countries \\
\hline Reforming the permanent establishment (PE) concept. & $\begin{array}{l}\text { Israel, Indonesia, India, } \\
\text { Slovakia, Saudi Arabia }\end{array}$ \\
\hline $\begin{array}{l}\text { Taxing digital payments by withholding at source and (or) extending the definition } \\
\text { of royalties to include digital payments. }\end{array}$ & Malaysia, Vietnam \\
\hline $\begin{array}{l}\text { Introduction of digital services tax (DST) or equalisation levies. By their design, } \\
\text { such taxes usually have low rates }(1.5-5 \%) \text {. Tax base is determined as the gross } \\
\text { amount of revenues obtained by foreign digitalised companies from local sources } \\
\text { (B2B or B2C). }\end{array}$ & $\begin{array}{l}\text { Austria, France, Hunga- } \\
\text { ry, Italy, India, Turkey, } \\
\text { United Kingdom }\end{array}$ \\
\hline $\begin{array}{l}\text { Introduction of specific tax regimes to tax the diverted profits of the largest MNEs } \\
\text { (including digitalised businesses). In fact, this is a special anti-avoidance rule devel- } \\
\text { oped into a separate tax regime to apply in parallel with existing international tax } \\
\text { treaties and not to be bound by the limitations of the existing tax treaties. }\end{array}$ & United Kingdom \\
\hline $\begin{array}{l}\text { Reforming the concept of corporate tax residence (definition of the place of 'effec- } \\
\text { tive management'). Most states do not set detailed algorithms for the application of } \\
\text { corporate tax residence criteria for digitalised businesses. Therefore, in practice, a } \\
\text { variety of criteria can be relevant, which would lead to legal uncertainty. }\end{array}$ & $\begin{array}{l}\text { India, South Africa, Chi- } \\
\text { na }\end{array}$ \\
\hline
\end{tabular}


because the virtual permanent establishment (PE, significant economic presence) concept introduced beforehand was de facto ineffective (Fuchs, Israel seeks, 2019). Application of the PE definition as extended to cover digital reality and virtual presence leads to treaty override and is therefore problematic (Fuchs, Analysts Evaluate, 2019). A similar situation happened in Slovakia. New legislative norms introduced there resulted in virtual PE for digital platforms. This situation resulted in the initiation of mutual agreement procedures by some of Slovakia's tax treaty partners that aimed to resolve their dispute about the treaty's interpretation (Stojaspal, 2018).

Considering the context described above, experts suggest that a multilateral solution is likely to be the only possible way forward (Simontacchi, 2020). The OECD has been working on such a multilateral solution, which by the end of 2020 contained blueprints with two pillars for reform. Pillar 1 included new rules on digital nexus and profit allocation for the largest MNEs that would lead to taxation of the residual profits of such companies based on their digital presence (on the level of sales of users in the market states) (OECD, Tax Challenges... Report on Pillar One, 2020). Pillar 2 is based on the idea of setting a global minimum corporate income tax rate for the undertaxed profits of the largest MNEs in order to set the limits of international tax competition and stop the remaining tax avoidance practices (base erosion and profit shifting issues) (OECD, Tax Challenges...Report on Pillar Two, 2020). Both ideas require an unprecedented level of tax cooperation among the players on the international tax stage, including policymakers, governments, tax administrations and MNEs.

Preliminary assessments by the OECD show that the enactment of both pillars of reform could result in tax revenue growth of USD100 billion globally (Martin, 2020). This estimation is in fact a lower threshold of the interval, indicating a potentially global loss of tax revenues due to the issues of base erosion and profit shifting and aggressive tax planning (USD100-240 billion). ${ }^{2}$

See, for example, OECD. (2020). International collaboration to end tax avoidance. Available at: https://www.oecd.org/
We suggest that the proposed reform could only partly contribute to achieving its goals, based on two arguments. First, each jurisdiction could still set its own tax rate and tax base, which would leave some room for new tax planning strategies and tax competition practices. Second, Pillars 1 and 2 require not only principles but also administrative mechanisms. Such mechanisms have been proposed by the OECD (OECD, Tax Challenges...Report on Pillar One, 2020); however, they are all built on the idea of early dispute prevention and resolution by a panel of tax administrations that is in fact another face of the binding arbitration mechanism. Binding arbitration can be against the domestic policy rules of many developing and emerging countries for reasons of political economy because of their contradicting economic interests with developed countries.

\section{Discussion of the Russian perspective on international tax challenges in a digitalised economy:} Challenges and proposals for moving forward

As the analysis above shows, both multilateral and unilateral solutions have their pros and cons. Russia must closely monitor these developments if it is to figure out its own strategy for adapting its tax system to global challenges. Some considerations that are important for a discussion of reforms to deal with the challenges of corporate taxation in a digitalised world are described below. These policy considerations have been developed from an initial draft report published by the authors of this article in Russian as a chapter of a book published by the Gaidar Institute of Economic Policy in 2021 (Rossiskaya ekonomika, 2021). The report was revised, extended and updated by the authors in consideration of recent changes in tax policy.

We do not limit the scope of our proposals to the problem of choosing between Pillar 1 and any of the unilateral solutions, but we discuss the potential reforms in the broader context of tax law, including corporate residence criteria, tax characterisation of supplies in digital form

tax/beps/ (accessed 5 June 2020). 
and taxation of royalties at the source state. The proposals are not intended to cover all the issues in relation to addressing the digital tax agenda, but rather to express some ideas that the authors consider important for current tax policy discussion in Russia.

\subsection{First challenge:}

\section{Taxing foreign businesses}

\section{with a virtual presence in Russia}

Current rules based on physical presence for tax nexus at source cannot effectively lead to taxation of the profits of foreign companies that were obtained from a digital presence in the market jurisdiction, and therefore they must be updated to reflect the economic interests of Russia as a large and growing market for digital businesses.

As of June 2021, there are no instruments in Russian tax law to tax the local profits of foreign digital companies with merely a virtual presence in Russia. This would lead to losses of revenue and a distortion of the competitive level playing field in the local market in favour of foreign digitalised companies.

In Table 3, the authors present their estimations of potential tax revenues as a result of multilateral (Pillar 1) and unilateral (digital services tax, DST) paths of digital tax reform in Russia. This is based on the delineation of the share of the Russian users of foreign digital companies' websites based on the geographical distribution of internet traffic (using data from the SimilarWeb portal ${ }^{3}$ as of April 2020). The steps and results of this analytical approach are presented below.

The authors' estimation shows that DST reform could generate RUB37.8 billion of additional revenues (based on 2019 financial data), which is about 4 times higher than Pillar 1 reform results. Tax revenues from Pillar 1 could be even lower, considering that Russia has its own digital platforms (Mail.ru and Yandex) that have a significant virtual presence in the markets of former Soviet Union states. Their income from this foreign virtual presence can be attributed to these foreign states and therefore credited in Russia under Pillar 1 rules.

\footnotetext{
3 https://www.similarweb.com/
}

Even considering these estimations, we cannot suggest that DST is a preferable option because it could lead to problems for international economic cooperation in the digital economy between Russia and developed states (US and other OECD member states). Considering that Russia is a net exporter of IT services, such co-operation and access to foreign markets is important for its companies. What is more, digitalised Russian companies working in foreign markets would be likely to pay more tax in high-tax jurisdictions, and their overall tax burden would be likely to increase due to unilateral digital tax measures introduced abroad.

DST may also be more fiscally efficient than Pillar 1 because it has a much simpler design and therefore requires fewer costs for administration and compliance. Russian tax administration is now reasonably developed and digitally savvy, and it could potentially administer DST. ${ }^{4}$ Recent experience of the introduction of VAT on B2C digital services in 2016 showed that foreign digital companies have been complying with Russian rules and remitting their VAT to Russian budgets. Pillar 1 methodology is still only at the developmental stage. It contains a number of highly complex technical issues that could potentially lead to disputes among states. The mechanism of early prevention and subsequent resolution of such disputes discussed in the 2020 Pillar 1 OECD Blueprint (OECD, Tax challenges...Report on Pillar One, 2020) requires the de facto transfer of part of sovereign tax administration capacity to multilateral level. Russia has little experience in participating in mutual agreement procedures and did not accept a 'mandatory binding arbitration' mechanism ${ }^{5}$ when

\footnotetext{
4 In particular, speaking at the session of the Forum on Tax Administration held in Chile in 2019, its head, Hans Christian Holte, pointed to the leadership of the Russian Federal Tax Service in shaping the experience of digitalisation of the tax sphere in the world. https://www.kommersant.ru/doc/3930370 5 According to an FAQ on the OECD's multilateral instrument, the 'mandatory binding arbitration is a mechanism which, in defined circumstances, obliges the parties to the treaty to submit unresolved issues in a MAP case to an independent and impartial decision-maker-an arbitration panel.' The decision reached by the arbitration panel is binding on the parties to the treaty and thus resolves the issues that can otherwise prevent agreement in deadlocked MAP cases.
} 
Table 3. Comparative analysis of revenues from joining Pillar 1 and the introduction of a digital services tax (DST) in Russia

\begin{tabular}{|c|c|c|}
\hline № & Pillar 1 OECD & DST at $5 \%$ rate \\
\hline 1 & \multicolumn{2}{|c|}{$\begin{array}{l}\text { Delineation of digital global companies based on their revenues (>EUR750 billion) and functions. Re- } \\
\text { sults show that key digital players on the Russian market include Google, Alibaba and Booking.com. }\end{array}$} \\
\hline 2 & \multicolumn{2}{|c|}{ Delineation of traffic to global websites from Russia and its share of overall traffic. } \\
\hline 3 & $\begin{array}{l}\text { We assume the same level of profitability }=20 \% \\
\text { and the same level of distribution of profits to mar- } \\
\text { ket jurisdictions (Amount A) }=40 \% \text { for calculat- } \\
\text { ing the Russia-sourced income. }\end{array}$ & $\begin{array}{l}\text { We multiply overall revenues on the share of Rus- } \\
\text { sian traffic to calculate the Russia-sourced DST tax } \\
\text { base. }\end{array}$ \\
\hline \multirow[t]{2}{*}{$4^{1}$} & Computation of result using CIT rate of $20 \%$. & Computation of result using DST rate of $5 \%$. \\
\hline & +RUB10 billion (equivalent to $\sim$ USD153.8 million). & $\begin{array}{l}\text { +RUB37.8 billion (equivalent to } \sim \text { USD581.5 mil- } \\
\text { lion). }\end{array}$ \\
\hline
\end{tabular}

Source: Compiled by the authors

1 The weighted average dollar exchange rate for IFRS purposes from 1 January 2019 to 31 December 2019 of 65 rubles was used. https://www.audit-it.ru/currency/sr_vz.php

it joined the OECD's multilateral instrument (MLI) (OECD, 2019). As explained by a Ministry of Finance official during a recent academic conference, Russia cannot accept sharing its tax sovereignty with foreign states for reasons broader than tax policy (including international politics). ${ }^{6}$

Considering the arguments discussed above, the following policy recommendations could be made to address the challenges mentioned at the beginning of this section. We suggest that Russia could introduce DST as an interim measure and subsequently cancel it if multilateral consensus regarding taxation of the digitalised economy were to be reached at OECD and BEPS project level.

The following notes explain our position in this regard:

1) Administrative simplicity and fiscal efficiency arguments outweigh the fairness and international consistency considerations in the

See: https://www.oecd.org/tax/treaties/MLI-frequently-askedquestions.pdf. Part VI of the MLI discloses the principles of the mandatory binding arbitration mechanism. https://www. oecd.org/tax/treaties/multilateral-convention-to-implementtax-treaty-related-measures-to-prevent-BEPS.pdf

6 From the speech of Ekaterina Vinogradova, Head of the International Tax Relations Division of the Tax Policy Department of the Ministry of Finance of the Russian Federation, at the Eurasian Tax Week (Financial University under the Government of the Russian Federation, Moscow, 23 March 2021). https://eurasiantaxweek.ru/ru/business-program/ current tax policy context. In other words, extending taxation rights would be a more pragmatic and achievable goal for Russian policymakers than the aim of consistently updating global rules.

2) From an economic perspective, DST fits well with Russia's role as an important market for foreign digitalised businesses, considering its large and increasingly digitally savvy population.

3) DST can compensate the a loss of budget revenues under the 2020 'IT-manoeuvre' tax reform that offered large tax reductions for Russian IT companies (i. e. reduction of social contribution rate from $14 \%$ to $7.6 \%$, reduction of corporate income tax rate from $20 \%$ to $3 \%$ and exemption from VAT only for Russian software ${ }^{7}$ ).

4) A number of foreign developing and developed countries have already introduced such unilateral measures, and it seems unlikely that these measures would reverse the expansion of global digitalised MNEs (especially during the COVID-19 pandemic, with

\footnotetext{
7 Notably, according to representatives of the US Trade Representative Office (USTR), the implementation of such a tax scenario leads to a distortion of the conditions of international competition. In this regard, USTR plans to assess how the implemented measures affect US exports, up to and including an appeal to the WTO, if they discriminate against US services exports. https://ustr.gov/sites/default/files/files/reports/2020/ Russia2020WTOReport.pdf
} 
such companies receiving fantastic profits). Therefore, Russia would be part of a global tax policy trend in this regard, considering the post-COVID-19 economic context and goals of fiscal consolidation and taxing residual windfall profits of digitalised businesses (UN, Tax challenges, 2017).

A separate discussion is likely to be needed to decide if such a tactical policy recommendation is valid in the context of the progress of multilateral tax cooperation, which has intensified during 2021 under the leadership of US Minister of Finance Janet Yellen. ${ }^{8}$ However, this global tax governance initiative is fundamentally not a total game-changer and still requires a great deal of technical work and policy discussion for it to be implemented. Therefore, uncertainty remains towards achieving a global solution, and key arguments in favour of potential Russian unilateralism in its digital tax reform path, as discussed above, are still valid.

\subsection{Second challenge:}

\section{Tax residence concept in digital reality}

Tax residence criteria for companies do not fit with the realities of the digitalised economy. Incorporation criteria are formal (thus, they could be avoided or manipulated), while the criteria for effective place of management are uncertain and could potentially lead to base erosion and profit shifting issues. This is because such locations could be moved to low-tax jurisdictions as the use of digital technologies for communication and remote management increasingly becomes standard practice.

As of June 2021, Article 247.2 of the Tax Code of the Russian Federation sets out two broad corporate residence criteria. First, Russian companies (companies legally registered in Russia) are Russian tax residents. Second, foreign companies and structures could be Russian tax residents if they are managed in Russia. At least one of the following conditions

\footnotetext{
8 See, for example: Wilkie, C. (2021, 1 July). 130 nations agree to support US proposal for global minimum tax on corporations. CNBC. Available at: https://www.cnbc. com/2021/07/01/nations-agree-to-support-us-proposal-forglobal-minimum-tax-on-corporations.html (accessed 21 July 2021).
}

must be fulfilled to trigger the second of these criteria:

- The company's management is performed by an executive body located in Russia on a regular basis.

- The company's management is performed by key executives for the most part in Russia.

Neither the tax code nor letters issued by Ministry of Finance directly address the question of what constitutes 'regular' management in a foreign company. The concept of managing 'for the most part' by key executives is also unclear (Volosov, 2019). That is why it is important to assess the volume and quality of the management function performed in Russia to answer the question of whether a foreign company is a Russian tax resident. Such an uncertain approach does not fit with socioeconomic realities of the digitalised future and is also not in line with Russia's interests in the context of developing its international tax policy.

Notwithstanding the efforts of Russian tax policymakers to de-offshorise the economy, the number of foreign companies and legal structures holding Russian assets is still considerable (Volosov, 2019). What is more, in 2018, Russia introduced a tax law with two new special administrative regions (SARs) in Vladivostok and Kaliningrad with preferential holding tax regimes for redomiciled foreign holding companies. However, the number of companies using these tax exemptions is still modest. ${ }^{9}$

At the same time, using foreign companies incorporated in Cyprus or other jurisdictions with preferential tax regimes for digital projects is a popular practice for Russian business in the IT and digital sector (Milogolov, 2020). Such companies can be regarded as CFC and, as such, their profits would be subject to tax in Russia at the amount attributed to the controlling person (Russian tax resident). However, a number of exemptions under Russian CFC rules can lead to a scenario whereby profits of foreign companies remain undertaxed in

\footnotetext{
9 With reference to an interview with Deputy Minister of Economic Development Ilya Torosov, we can conclude that, as of October 2020, 36 companies were residents of SARs. In our opinion, however, we can expect an increase in this number due to the revision of double tax treaties. https://www.interfax. $\mathrm{ru} /$ interview/734972
} 
Russia. Exemptions apply to companies that receive less than $80 \%$ of their profits from active business and to purely holding and subholding companies (Article 25.13-1 of the Tax Code of the Russian Federation). In the case of digital businesses, if corporate entities that collect payments for digital services or provide IP rights for software are located in foreign low-tax countries, profits could be attributed to such foreign entities and the Russian tax base would be eroded.

Therefore, we suggest amending the corporate tax residence criteria in Russia with the aim of ensuring its taxation rights as a state of residence in the context of virtual businesses. We propose two ideas for such a reform. First, assessment of the economic functions performed by a company in each state, and analysis of key executives' place of permanent residence (or place of vital interests), would serve as useful extensions to the existing criteria for corporate residence under Russian domestic law. South Africa's experience could be useful in this regard (SARS, 2012). Second, formalisation of corporate tax residence criteria could also ensure tax certainty. Analysis of the geographical distribution of a company's assets and employees could serve as valuable evidence to support the conclusion of its economic nexus with Russia as its state of residence.

This would also be important for applying tax treaties in the case of conflict over double tax residence. It would be likely that such conflict could be resolved under a mutual agreement procedure between respective competent authorities. The design of this dispute resolution mechanism for Russian tax treaties and domestic legislation was recently updated after Russia joined the MLI (OECD, Multilateral Convention, 2020).

\subsection{Third challenge:}

\section{Tax characterisation of digital supplies}

There is uncertainty over the tax characterisation of supplies in digital form under double tax treaties and domestic tax legislation. This uncertainty creates risks both for the taxpayer and in tax administration, in that taxpayers would not be certain of their future tax liabilities, and therefore anticipated after-tax income, while there is also the risk of underpayment and tax avoidance for tax administrators.

Analysis Russia's tax law has led us to observe a high level of uncertainty in the classification of income received by foreign companies from the provision of digital supplies under licence agreements. Different characterisations lead to varying levels of taxation for such income due to differing rules covering the taxation of royalties and business income in domestic law and tax treaties. The level of taxation can be either more or less favourable, which depends on a number of factors and circumstances in each case.

Licence agreements limit the use of intellectual property by the licensee. Any such transaction can contain the transition of part of full copyright, other author's rights, know-how or secret formula. Therefore, complex analysis is needed to determine the category of income received under a license agreement. The Ministry of Finance has clarified ${ }^{10}$ that it follows the de minimis approach recommended by the OECD (OECD, 2017). The qualitative characteristic of transferred rights is a key criterion for determining if such supply can be classified either as a royalty or business income.

In the case of mixed contracts (for provision of goods/services and some IP rights), it is unclear if the taxpayer should determine the main goal of such transactions or delineate each type of supply separately. The Commentaries on the OECD Model Tax Convention (2017) (OECD, 2017) recommend the latter approach. There is no explicit guidance or court practice dealing with this issue in Russia.

Considering the importance of creating neutral, stable and definitive rules for digital and non-digital sectors of the economy, we suggest that addressing the technical issues of digitalisation should be a key focus for Russian tax policymakers. As indictors outlining Russia's approach to these issues, we suggest using the de minimis principle as a key criterion for differentiation between royalties and busi-

\footnotetext{
${ }^{10}$ See, for example: Letter of the Ministry of Finance No. 03-08-05/19799. (2021, 19 March). Available at: http://taxpravo.ru/zakonodatelstvo/statya-443394-pismo_minfina_rossii_ot_19032021_g_03_08_05_19799 (accessed 21 July 2021).
} 
ness income that is already used in the Commentary to the OECD Model Tax Convention (2017) (OECD, 2017) and also the tax legislation of foreign states such as Singapore (IRAS, 2013). We do not support the recent initiative of the UN Committee of Experts in Tax Issues to extend the definition of royalties so that it includes any kind of payment for the use of software (UN, 2020). This is because such an approach would be likely to devalue different approaches to the taxation of income of a business or capital nature, and thus the economic principles of international taxation.

What is more, the first part of the Russian tax code, which contains key definitions, requires an update. For example, the definition of services in Article 38 (5) is outdated and does not fit with the definition of e-services for VAT purposes in Article 174.2 (See Table 4).

While Article 38 (5) of the tax code sets 'consumption in the process of creation' as the key criterion for services, Article 174.2 is broader and sets its key criteria as 'automatism' and 'the use of information technology and the internet'. For example, transferring industrial data for improving the process of manufacturing goods or for a 3D printing business can fall under the definition of e-services in Article 174.2 but outside the definition of Article 38. This creates uncertainty in tax outcomes and the application of place of supply rules for services in an international context.

The inconsistencies between the development of different sets of rules in Russian tax legislation in the context of digitalisation is an important issue not only for VAT but also CIT and other taxes. A common approach is needed for this to be updated; otherwise, constant conflicts would be likely between rules applied for the purpose of defining tax liabilities under different taxes (e. g. VAT and CIT) and under domestic rules or rules governed by international tax treaties.

\subsection{Fourth challenge: \\ Taxation of royalties at source}

The existing mechanism for the taxation of royalties by withholding at source on a gross basis is not economically well founded. Taxation of gross income can result in overtaxation for the foreign licensor because it does not account for costs related to the development of intellectual property (IP). This problem is relevant for the digital agenda because R\&D function of IP is significant for digital businesses.

Under domestic tax legislation (Article 309 of the tax code), royalties paid to nonresidents (without permanent establishment) in Russia are taxed at a rate of $20 \%$ on a gross basis. Such a cost can be deducted from the tax base of the royalty payer at the level of a Russian company exploiting this IP.

The mechanism of taxing royalties on a gross basis is not commensurate with the costs related to the development, enhancement, maintenance, protection and exploitation (DEMPE) of the IP. Neither does it correctly account for $R \& D$ costs incurred by the creator of the IP. This problem could in theory be resolved either by exempting royalties from taxation at source or by taxing them on a net basis. Full exemption of royalties at source creates the risk of base erosion and profit shifting, especially in the context of Russia's emerging economy, as explained in the paragraph below. Taxation

Table 4. The difference in definitions of 'services' in the Tax Code of the Russian Federation

\begin{tabular}{|l|l|}
\hline \multicolumn{1}{|c|}{$\begin{array}{c}\text { General definition of services } \\
\text { for tax purposes (Article 38 (5) of the tax code). }\end{array}$} & \multicolumn{1}{c|}{$\begin{array}{c}\text { Specific definition for international VAT } \\
\text { purposes of services provided } \\
\text { in electronic form (Article 174.2 of the tax code). }\end{array}$} \\
\hline $\begin{array}{l}\text { 'Services' for the purpose of taxation are defined as } \\
\text { activities resulting in intangible character that are con- } \\
\text { sumed and supplied in the process of their creation. }\end{array}$ & $\begin{array}{l}\text { For the purposes of this chapter, the supply of services } \\
\text { in electronic form is defined as the supply of services } \\
\text { through information-telecommunication network 'In- } \\
\text { ternet' automatically and with the use of information } \\
\text { technology. }\end{array}$ \\
\hline
\end{tabular}

Source: Compiled by the authors 
of royalties on a net basis is a methodologically and administratively complex idea and is also discussed below.

Our analysis of data at a macro level (performed at 2018) showed that there is a bias in the geographical structure of jurisdictions that receive royalties from Russia in favour of so-called 'transit jurisdictions'. These jurisdictions can be defined as countries with an abnormally high level of royalties received in relation to $R \& D$ spending in their economies and also an abnormally high level of FDIs in relation to the size of their GDP. Tax treaties between Russia and these jurisdictions usually contain a zero rate for outbound royalties at the source state (Ireland, Switzerland, Cyprus, the Netherlands and Luxembourg) (Berberov, Milogolov, 2018). Therefore we can suggest that companies and SPEs incorporated in such jurisdictions are artificially included in MNE corporate structures for tax planning purposes, while most of the substantive functions relating to intangible assets (triggering the payment of royalties) are in fact located in other jurisdictions. That is why exempting royalties at the source state creates the fiscal risk of base erosion and profit shifting.

In the context of discussing the taxation of royalties on a net basis, the following options to account the costs incurred by the licensor are potentially available (Trepelkov, 2015):

- Unfinal withholding tax, whereby the foreign licensor can deduct all or only specially mentioned types of costs against income received.

- Application of withholding tax at lower rates, which results in taxation of the anticipated (deemed) net financial result of the licensor.

- Taxing only part of the gross amount of royalties paid.

Our suggestions for reforming the mechanism of withholding the taxation of royalties in Russia include several ideas:

1) Lowering the domestic withholding tax rate for outbound royalties (currently set at $20 \%$ ) to $10 \%$.

2) Renegotiating a higher withholding tax rate for royalties in Russian bilateral tax trea- ties (especially in treaties with 'transit jurisdictions' mentioned above).

3) Allowing the credit of part of foreign companies' expenses related to the creation and development (including R\&D) of the object triggering royalty payments equal to the amount of costs incurred on the territory of Russia, or if such R\&D was outsourced, to Russian contractors (subcontractors).

Such an approach is based on the following policy considerations. First, it protects against aggressive tax planning in the form of misclassification of other types of income into royalties (UN, Protecting the Tax Base, 2017). Second, it is in line with the policies of most emerging countries, where outbound royalties are usually taxed at non-zero rate at source (Deloitte, 2021), and it protects against tax avoidance in the form of structuring IPs into low-tax hub jurisdictions (UN, United Nations Model, 2017). Finally, crediting expenses incurred in Russia can serve as a tax incentive for foreign companies to locate their R\&D facilities on Russian soil and thus develop Russia's potential in R\&D.

\section{Conclusion / summary of key results}

Today we are seeing a revolution in corporate tax reform at an international level. ${ }^{11}$ This reform is based on arguments following on from a discussion of the impact of digitalisation on the global economy, business practices, society and international corporate tax law. One of key aspects of this discussion is how the taxation rights of states will be spread in the new reality among emerging and developed states and also between countries where digitalised businesses are based and countries where such businesses earn their revenues. Co-ordination of tax policy is crucial for levelling the playing field for international digitalised businesses and ensuring that the tax base is not eroded at global or national level. Some countries have been taking unilateral measures to ensure their tax sovereignty in the new digital economic reality, marking their

\footnotetext{
${ }^{11}$ See: G20. (2021, 9-10 July). Communique of the Third G20 Finance Ministers and Central Bank Governors meeting. 3rd Finance Ministers and Central Bank Meeting. Available at: https://www.g20.org/wp-content/uploads/2021/07/ Communique-Third-G20-FMCBG-meeting-9-10-July-2021. pdf (Accessed 21 July 2021).
} 
Table 5. The digital economy and proposals for reforms in Russia

\begin{tabular}{|l|l|}
\hline \multicolumn{1}{|c|}{ Challenge } & \multicolumn{1}{|c|}{ Solution } \\
\hline $\begin{array}{l}\text { Absence of taxation of business profits of foreign com- } \\
\text { panies or those without a physical presence in Russia. }\end{array}$ & $\begin{array}{l}\text { DST as an interim measure and subsequently joining } \\
\text { the OECD's Pillar 1 proposal. }\end{array}$ \\
\hline $\begin{array}{l}\text { Corporate tax residence criteria can be manipulated in } \\
\text { a digital business reality. }\end{array}$ & $\begin{array}{l}\text { New formalised mechanical criteria for corporate resi- } \\
\text { dence based on geographical distribution of assets and } \\
\text { key executive staff. This can show an economic nexus } \\
\text { with Russia. }\end{array}$ \\
\hline $\begin{array}{l}\text { Uncertainty in tax characterisation of supplies in digi- } \\
\text { tal form under domestic tax rules and double tax trea- } \\
\text { ties. }\end{array}$ & $\begin{array}{l}\text { Profound re-writing of tax definitions to fit with the } \\
\text { new digital reality in first (general) and second (spe- } \\
\text { cific) parts of the tax code. Harmonisation of charac- } \\
\text { terisation rules, definitions and criteria for VAT, CIT } \\
\text { and tax treaties. }\end{array}$ \\
\hline $\begin{array}{l}\text { Withholding tax on royalties creates the risk of base } \\
\text { erosion and profit shifting in the case of licensors re- } \\
\text { siding in treaty 'transit' jurisdictions and excessive } \\
\text { taxation in the case of licensors residing in non-treaty } \\
\text { countries and 'non-transit' treaty jurisdictions. }\end{array}$ & $\begin{array}{l}\text { Applying same withholding tax rates for royalties paid } \\
\text { from Russia to licensors located in treaty and non- } \\
\text { treaty states (after renegotiating tax treaties with tran- } \\
\text { sit jurisdictions). Crediting R\&D expenses incurred on } \\
\text { Russian territory against the royalty revenues taxed at } \\
\text { source. }\end{array}$ \\
\hline
\end{tabular}

Source: compiled by the authors

'virtual borders' and 'virtual territories' under their tax jurisdictions. This tax policy agenda is relevant for Russia, considering its role as key market for digitalised businesses. Therefore, the authors' recommendations that are summarised in Table 5 are relevant for a tax policy discussion of further adaptation of Russian tax rules for a digitalised reality.

\section{References}

Berberov, A., Milogolov N. (2018). Ocenka masshtabov problemy razmyvanija nalogovoj bazy v Rossii [Assessment of the scope of tax base erosion in Russia]. In Finansovyj zhurnal [Financial Journal]. June 2018, 47-58. DOI: 10.31107/2075-1990-2018-6-47-58

Dagan, T. (2017). The future of corporate residency (Research paper No. 18-14). Bar Ilan University Faculty of Law. Available at: https:/law.huji.ac.il/sites/default/files/law/files/the_future_of_corporate_residence.pdf (Accessed 5 June 2021).

Deloitte (2021). Treaty rates. Available at: https://dits.deloitte.com/\#TaxTreatySubMenu (Accessed 5 June 2021).

Devereux, M. P., Vella, J. (2017). Implications of digitalization for international corporate tax reform: Working paper. Oxford University Centre for Business Taxation. Available at: https://core.ac.uk/download/ pdf/288289068.pdf (Accessed 5 June 2021).

Hadzhieva, E. (2019). Impact of digitalisation on international tax matters: Challenges and remedies. Directorate-General for International Policies, European Parliament Policy Department for Economic, Scientific and Quality of Life Policies. Available at: https://www.europarl.europa.eu/cmsdata/161104/ST\%20 Impact\%20of\%20Digitalisation\%20publication.pdf (Accessed 5 June 2021).

Fuchs, H. (2019, 19 May). Analysts evaluate Israel Tax Authority's plans for a digital tax. Pearl Cohen. Available at: https://www.pearlcohen.com/analysts-evaluate-israel-tax-authoritys-plans-for-a-digital/ (Accessed 5 June 2021).

Fuchs, H. (2019, 28 May). Israel seeks introduction of a digital sales tax. International Tax Review. Available at: https://www.internationaltaxreview.com/article/b1fm4mbq473f4p/israel-seeks-introductionof-a-digital-sales-tax (Accessed 5 June 2021). 
IRAS (2013). IRAS e-tax guide: Rights-Based Approach for Characterising Software Payments and Payments for the Use of or the Right to Use Information and Digitised Goods. Inland Revenue Authority of Singapore. Available at: https://www.iras.gov.sg/irashome/uploadedFiles/IRASHome/e-Tax_Guides/etaxguides_CIT_rights-based\%20approach_2013-02-08.pdf (Accessed 5 June 2021).

Kostíc, S. V. (2019). In search of the digital nomad: Rethinking the taxation of employment income under tax treaties. World Tax Journal, 11 (2), 189-225.

Lucas-Mas, C. Ó., Junquera-Varela R. F (2021). Tax theory applied to the digital economy: A proposal for a digital data tax and a global internet tax agency. Washington, DC, World Bank Publications, p. 135.

Martin, J. (2020, 13 February). Global tax rewrite could cost multinationals USD100 billion annually, OECD says. MNE Tax. Available at: https://mnetax.com/global-tax-rewrite-could-cost-multinationalsusd-100-billion-annually-oecd-says-37681 (Accessed 5 June 2021).

Milogolov, N. (2020). The emergence of the 'technological tax hub': Digitally oriented trajectories of reforms in tax planning hub jurisdictions. Intertax, 48 (12), 1105-1124.

$O b$ opredelenii mesta upravlenija inostrannoj organizaciej dlja priznanija ejo rezidentom $R F$ dlja celej naloga na pribyl' (2017). [About defining place of management of foreign company for purposes of recognizing it as resident of Russia for corporate income tax purposes]. Available at: https://www.eg-online.ru/ document/regulatory/342351/ (Accessed 5 June 2021).

OECD (2015). BEPS actions. Available at: https://www.oecd.org/tax/beps/beps-actions/ (Accessed 21 July 2021).

OECD (2017). Model tax convention on income and on capital: Condensed version (2017). Available at: https://www.oecd.org/ctp/treaties/model-tax-convention-on-income-and-on-capital-condensedversion-20745419.htm (Accessed 5 June 2021).

OECD (2018). Tax challenges arising from digitalisation - Interim report. Available at: https://www. oecd.org/ctp/tax-challenges-arising-from-digitalisation-interim-report-9789264293083-en.htm (Accessed 5 June 2021).

OECD (2019). Russian Federation - Status of list of reservations and notifications at the time of signature. Available at: https://www.oecd.org/tax/treaties/beps-mli-position-russian-federation-instrumentdeposit.pdf (Accessed 21.07.2021).

OECD (2020). Multilateral convention to implement tax treaty related measures to prevent base erosion and profit shifting. Available at: https://www.oecd.org/tax/treaties/multilateral-convention-toimplement-tax-treaty-related-measures-to-prevent-BEPS.pdf (Accessed 5 June 2021).

OECD (2020). Tax challenges arising from digitalisation - Report on pillar two blueprint. Available at: https://www.oecd.org/tax/beps/tax-challenges-arising-from-digitalisation-report-on-pillar-twoblueprint-abb4c3d1-en.htm (Accessed 5 July 2021).

OECD (2020). Tax challenges arising from digitalisation - Report on pillar one blueprint. Available at: https://www.oecd.org/tax/beps/tax-challenges-arising-from-digitalisation-report-on-pillar-one-blueprintbeba0634-en.htm (Accessed 21 July 2021).

OECD (2021). Updated guidance on tax treaties and the impact of the COVID-19 pandemic. Available at: https://read.oecd-ilibrary.org/view/?ref=1060_1060114-o54bvclga2\&title=Updated-guidance-on-taxtreaties-and-the-impact-of-the-COVID-19-pandemic (Accessed 21 July 2021).

Rossijskaja ekonomika v 2020 godu. Tendencii i perspektivy. (Vyp. 42) [The Russian economy in 2020. Trends and Prospects. (Issue 42)] (2021). Available at: https://www.iep.ru/files/text/trends/2020/Book.pdf (Accessed 21 July 2021).

Simontacchi, S. (2020, 3 February). Insight: Possible double taxation behind the Italian digital services tax. BloombergTax. Available at: https://news.bloombergtax.com/daily-tax-report-international/ insight-possible-double-taxation-behind-the-italian-digital-services-tax (Accessed 5 June 2021).

SARS (2012). Interpretation note: No. 6 (Issue 2). Available at: https://www.sars.gov.za/wp-content/ uploads/Legal/Notes/LAPD-IntR-IN-2012-06-IN-6-Resident-Place-of-effective-management-companies. pdf (Accessed 5 June 2021). 
Stojaspal, J. (2018, 30 July). Slovakia pushing for tax from Expedia, Booking.com (1). Bloombergtax. Available at: https://news.bloombergtax.com/daily-tax-report-international/slovakia-pushing-for-tax-fromexpedia-bookingcom-1 (Accessed 5 June 2021).

Trepelkov, A., Tonino, H., \& Halka, D. (Eds.) (2015). United Nations Handbook on selected issues in protecting the tax base of developing countries. New York, United Nations, p. 593.

Reuters Staff. (2020, 24 January) U.S. warns of possible counter-measures against Czech digital tax. Reuters. Available at: https://www.reuters.com/article/us-europe-digitaltax-czech/u-s-warns-of-possiblecounter-measures-against-czech-digital-tax-idUSKBN1ZN0ZN (Accessed 5 June 2021).

United Nations. (2017). Protecting the tax base of developing countries against base-eroding payments: Rent and royalties. United Nations Department of Economic and Social Affairs. Available at: https://www.un.org/esa/ffd/wp-content/uploads/2017/05/PP_Rents-Royalties.pdf (Accessed 5 June 2021).

United Nations. (2017). Tax challenges in the digitalized economy: Selected issues for possible committee consideration. United Nations Committee of Experts on International Cooperation in Tax Matters, $15^{\text {th }}$ Session. Available at: https://www.un.org/esa/ffd/wp-content/uploads/2017/10/15STM_CRP22_-DigitalEconomy.pdf (Accessed 21 July 2021).

United Nations. (2020). Discussion draft: Possible changes to the United Nations Model Double Taxation Convention between developed and developing countries concerning inclusion of software payments in the definition of royalties. United Nations Committee of Experts on International Cooperation in Tax Matters. Available at: https://www.un.org/development/desa/financing/sites/www.un.org.development.desa. financing/files/2020-09/Revised\%20discussion\%20draft\%20final.pdf (Accessed 5 June 2021).

United Nations. (2021). United Nations Model Double Taxation Convention between developed and developing countries. United Nations Department of Economic and Social Affairs. Available at: https://www. un.org/esa/ffd//wp-content/uploads/2018/05/MDT_2017.pdf (Accessed 5 June 2021).

Volosov, I., Demenkov, A. (2019). Mezhdu deofshorizaciej i globalizaciej [Between de-offshorization and globalization]. Available at: https://www.spark-interfax.ru/articles/mezhdu-deofshorizatsiey-iglobalizatsiey (Accessed 5 June 2021). 